\title{
78. 若年海外高度人材が期待する日本での移住生活像の特徵に関する研究
}

\author{
-米国・スウェーデン・台湾・タイの4カ国の大学生を対象としたアンケート調査を用いて-
}

\section{Study on Young Foreign High Skilled People's Lifestyle Image of Migration in Japan}

- By Questionnaire Survey on University Students in USA, Sweden, Taiwan, and Thailand -

佐藤 遼*・柏崎 梢**・伊藤 弘基***・李 度潤* Ryo SATO*, Kozue KASHIWAZAKI**, Hiroki ITO***, and Toyun LEE*

The purpose of this thesis is to clarify the feature of young foreign high skilled people's lifestyle image of migration in Japan. The method is questionnaire survey on university students in USA, Sweden, Taiwan, and Thailand. As a result, the interests of migration to Japan were related with the interests in Japanese language, food, culture, QOL, lifestyle in islands, and international exchange program. On the other hand, the interest of migration to other countries were related with the interests in the countries' attractive environment of work and education, which means cultural attractiveness of those countries were less related with the interest of migration than Japan. These results implicates the importance of promoting cultural attractiveness of Japan to facilitate the migration of young foreign high skilled people.

Keywords: Migration, High Skilled People, Regional Image, Cultural Attractiveness, International Exchange 移住，高度人材，地域イメージ，文化的魅力，国際交流

\section{1. 研究の背景と目的}

\section{1-1. 背景}

日本では人口減少による内需の縮小に直面する中、外国 人との交流を促進する動きが国土政策として進められてい る。例えば、2015 年に国土交通省が制定した最新の国土形 成計画 (全国計画) 1)では、「対流促進型国土の形成」が目 標として掲げられている。この中では、国内の都市・地方 間などの対流に加えて、国内と海外との間でも国際的なヒ 卜、モノ、カネ、情報の対流を促進寸ること、例えば旅行 者の積極的受入れ、工業製品、農林水産品を始めとする特 産品等の輸出増加などが挙げられている。これと同時に、 海外との対流においては、人々の考え方、習慣、その背景 にある文化、歴史、風土等の違いを十分認識し、向き合っ ていく必要がある、とも述べられている。また、内閣府地 方創生推進事務局が管轄する国家戦略特区では、地域を限 つて外国人人材の受入の促進施策も行われている。例えば、 2016 年 4 月時点の東京圏の区域計画 2 )では、外国人創業活 動促進事業や、家事支援外国人受入事業が位置づけられ、 出入国管理及び難民認定法の特例として、基淮を満たす外 国人の上陸受入などの促進事業が行われる予定である。

一方、法制度としては、高度人材ポイント制による出入 国管理上の優遇制度が、2012 年より法務省入国管理局によ り導入されている。この制度は、「高度学術研究活動」、高 度専門・技術活動」「高度経営・管理活動」の3つの活動 を行う海外高度人材を、「学歴」、職歴」「年収」などの項 目ごとにポイントを設け，ポイントの合計が一定点数に達 した場合に, 出入国管理上の優遇措置を与えることにより、 高度人材外国人の我が国への受入れ促進を図ることを目的 としている 3)。他方で、この制度による受入の実績は当初 の見込みを大幅に下回っており、その要因として、日本で
は諸外国と異なり永住の権利が制度的に保障されておらず、 優先的な移住先として選ばれにくい、などの指摘がある ${ }^{4)}$

他方で、国際交流の促進政策としては、「COOLJAPAN」 や「ソフト・パワー」と呼ばれる日本の文化的魅力を活用 した政策が継続的に実施されてきた。代表的なものとして、 経済産業省などが主導する輸出による経済的利益を志向す る活動(1)と、外務省などが主導する「パブリック・ディプ ロマシー (文化外交)」と呼ばれる外交的な利益を志向する 活動(2)が存在する。このうち、後者の例としては、国際親 善交流や留学生の受け入れ、海外における語学教育の促進 などが挙げられる7)(3)。

また、近年はこのような文化的魅力の訴求が、若年世代 の移住へと発展する現象も見られる。例えば、米国の文化 産業への従事を目的とし、経済的理由ではない動機により 移住する「文化移民」の事例が報告されている ${ }^{8)}$ 。さらに、 国際的に活躍する高度人材が移住先に求める条件(4)の $1 つ$ に、地域の商品やサービスに対して文化的差異の消費を楽 しめることを挙げる主張も存在する ${ }^{9)}$ 。

\section{$1-2$. 目的}

これらを踏まえると、海外若年世代の一時的な滞在や移 住による国際交流の意向が、対象地域の文化的魅力八の関 心と関係がある、という仮説が考えられる。また、日本に おいては、海外諸国と比較して脆弱な永住の権利に関する 制度的な保証を改善するだけでなく、地域の文化的魅力を 訴求することも、高度人材の誘致を促進する上で重要な要 因となる可能性が考えられる。本研究では、若年海外高度 人材が期待する日本と海外諸国での移住生活像の特徵の分 析を通じて、前述の仮説を検証することを目的とする。

以下、2 章で調査・分析の方法、3 章で日本への移住の 関心の特徵と関係する要因、4 章で海外諸国への移住の関

\footnotetext{
* 正会員 東京大学大学院 工学系研究科 (The University of Tokyo, Faculty of Engineering)

** 正会員 東洋大学 国際地域学部 (Toyo University, The Faculty of Regional Development Studies)

***正会員 NPO 法人 うつくしまNPO ネットワーク (Utsukushima NPO Network)
} 
心の特徴と関係する要因について報告する。

なお、本研究では若年海外高度人材を、将来的に海外に 居住するキャリアを選好し、かつ大卒以上の学歴取得を目 指しており日本に移住した際に高度人材と認定される可能 性が高い外国人と考え、調査対象の選定条件として用いた。

\section{$1-3$. 先行研究の概要}

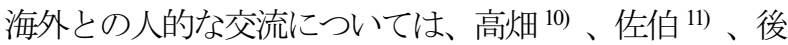
藤 12) などのように出入国管理や外国人登録などの政府統 計データを分析した研究が存在するが、本研究のように現 地に訪問して一次情報を自ら調查し分析した研究は少ない。 都市計画分野では、外国人の観光イメージに関する研究 ${ }^{13)}$ 、

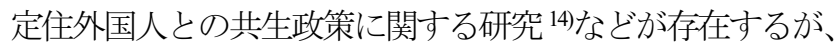
海外高度人材の日本一の移住関心について定量的に分析し た研究は見られない。一時的に居住・滞在する外国人につ いては、前述の多文化共生政策の研究に加えて、高度人材・

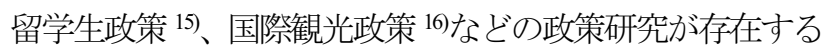
が、文化的魅力への着目は総じてあまり強くない。

\section{2. 調查 $\cdot$ 分析の方法}

\section{2-1. 調査・分析方法の概要}

研究方法として、米国・スウェーデン・台湾・タイの 4 力国の国際的な大学に所属する日本人以外の大学生に対し て、日本と海外諸国への移住の関心についてアンケート調 查を実施し、その結果を分析した。また、アンケート調査 の実施にあたっては、事前に現地に訪問し調査協力者を選 定し協力を依頼するとともに、アンケート調査と同様の質 問内容で集団面接調査を現地で実施し、アンケート回答の 理由として考えられる定性的情報を参考として収集した(5)。

調査では、日本と他の海外諸国について、就学及び就労 目的での関心の有無と移住先一の地域の魅力に関する評価

（5段階）を質問した。この結果を用いて、移住先の地域 の魅力に関する項目に平均值のクロス集計と $\mathrm{t}$ 検定の両側 検定を適用し、移住への関心の有無によって有意な差が見 られるか検証した（3-1で日本、4-1で海外諸国)。ま た日本と日本以外で最も居住したい海外諸国群を対象に、 生活へのイメージや生活に関する政策的支援等を質問し、 同様の分析を行った $(3-2$ で日本、 $4-2$ で日本以外に 最も居住したい海外諸国)。これにより 3 章では日本、4 章 では海外について、それぞれへの移住の関心の特徵やそれ に関する要因を分析した。

\section{2-2. アンケート調查の実施方法}

アンケート調査は、台湾の台湾大学、タイのチュラロン コーン大学とアジア工科大学、米国のハーバード大学とカ リフォルニア大学バークレー校、スウェーデンのルンド大 学の学生に対して実施した。日本との国際的な学術交流が 継続的に行われており、学生が高度人材として日本に移住 した実績が多く存在する大学のうち、調査への協力が得ら れた大学を米州、欧州、東アジア、東南アジアの特徵の異 なる 4 地域に分散するように選定した。現地に滞在する日 本人学生、または日本に関連寸る研究・教育実績がある現
地の大学教員に複数のルートで依頼し、友人・知人、講義 受講生等の外国人学生を対象にアンケートを配布してもら い、可能な限り回答を収集する方法を用いた。

アンケートは英語で実施した。英語の読解が苦手な回答 者も少し見られたが、調查協力者が翻訳して解説すること により回答を支援した。また、調査協力者が自身の環境に おいて回答を多く集めやすいと考えた方法を各地で選択し、 調查協力者 $\mathrm{A} \sim \mathrm{E}$ については紙の質問用紙で、調查協力者 F〜J についてはインターネットの Web サイトで回答を依 頼した。有効回答数は 303 件となった(6)。（表 1 ）

\section{表 1 アンケートの回収方法}

\begin{tabular}{|c|c|c|c|}
\hline 回答収集ルート & 回収数 & 国別 & 回収数 \\
\hline 台湾: 協力者A(台湾大学) & 34 & 台湾計 & 99 \\
\hline 台湾:協力者B (台湾大学) & 65 & 口污向 & \\
\hline タイ:協力者C (チュラロンコーン大学 $)$ & 31 & \multirow{4}{*}{ タイ計 } & \multirow{4}{*}{79} \\
\hline タイ:協力者D（チュラロンコーン大学） & 20 & & \\
\hline タイ:協力者E(アジアエ科大学) & 10 & & \\
\hline タイ:協力者F(チュラロンコーン大学とアジアエ科大学) & 18 & & \\
\hline 米国:協力者G(ハーバード大学) & 30 & \multirow{3}{*}{ 米国計 } & \multirow{3}{*}{70} \\
\hline 米国:協力者H(ハーバード大学) & 10 & & \\
\hline 米国:協力者I(バークレ一校) & 30 & & \\
\hline スウェーデン:協力者」(ルンド大学) & 55 & スウェーデン計 & 55 \\
\hline \multicolumn{3}{|l|}{ 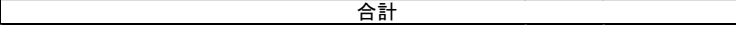 } & 303 \\
\hline
\end{tabular}

\section{2-3. アンケート調查の対象者の特徴}

調査の冒頭で、自身のキャリアにおける海外での居住経 験の重要性を5段階評価で質問したところ、いずれの回答 収集ルートとも、平均点が 5 点（Very Important）と 4 点

（Somewhat Important）の間の高い点数となった（表 2)。 また、将来就業を希望する職業についても自由回答式で質 問したが、概ね自身の大学での専攻を活かした職業に就業 することを希望する傾向にあった。このことから、いずれ の回答収集ルートでの調査対象者も、1-2で定義した海 外若年高度人材の条件を満たしていると考えられる。

\section{表 2 海外での居住経験の重要性の平均点（5段階評価）}

\begin{tabular}{|c|c|c|c|c|c|c|c|c|c|c|}
\hline \multicolumn{2}{|c|}{ 台湾 } & \multicolumn{4}{|c|}{ タイ } & \multicolumn{3}{|c|}{ 米国 } & SW & \multirow{2}{*}{ 全体 } \\
\cline { 1 - 10 } A & $\mathrm{B}$ & $\mathrm{C}$ & $\mathrm{D}$ & $\mathrm{E}$ & $\mathrm{F}$ & $\mathrm{G}$ & $\mathrm{H}$ & $\mathrm{I}$ & $\mathrm{J}$ & \\
\hline 4.0 & 4.0 & 4.2 & 4.2 & 4.4 & 4.3 & 4.7 & 4.3 & 4.1 & 4.1 & 4.1 \\
\hline
\end{tabular}

他方、調査対象者の性別、年齢、国籍、専攻の傾向には、 回答収集ルート間で偏りが存在する (表 3)。女性比率は専 攻と関係があることが考えられる。平均年齢の高さは修 士・博士課程学生比率と相関が強い。遠方留学生比率は、 台湾では東アジア以外、タイでは東南アジア以外、米国と スウェーデンでは欧米圈以外の国籍の比率を示しており、 中国・シンガポールなどのアジア圈からの留学生が多い場 合に高い值となる。専攻は協力者の専門分野に影響を受け ていると考えられるが、専攻に依存しないコミュニティの 調查協力者に依頼した場合には明確な偏りが出ていない。

これらのバイアスの存在により、アンケートの単純集計 結果は、調査対象者の在住地域や国籍ごとの傾向を代表す るものではない点に注意が必要である。 
表 3 回答収集ルートごとの属性の傾向

\begin{tabular}{|c|c|c|c|c|}
\hline 回答収集ルート & 女性比率 & 平均年齢 & 遠方留学生率 & 専攻の偏り \\
\hline 台湾: 協力者A & $84 \%$ & 21 & $6 \%$ & 農学(約90\%) \\
\hline 台湾:協力者B & $46 \%$ & 22 & $2 \%$ & 土木工学(約25\%) \\
\hline タイ:協力者C & $35 \%$ & 21 & $0 \%$ & 明確な偏りなし \\
\hline タイ:協力者D & $55 \%$ & 22 & $0 \%$ & 建築·都市デザイン $(100 \%)$ \\
\hline タイ:協力者 $\mathrm{E}$ & $50 \%$ & 27 & $0 \%$ & 都市環境学(100\%) \\
\hline タイ:協力者F & $33 \%$ & 22 & $0 \%$ & 政策科学(約50\%) \\
\hline 米国: 協力者 $G$ & $33 \%$ & 20 & $17 \%$ & 明確な偏りなし \\
\hline 米国: 協力者H & $70 \%$ & 32 & $20 \%$ & 明確な偏りなし \\
\hline 米国:協力者I & $23 \%$ & 28 & $20 \%$ & 都市·環境デザイン $(100 \%)$ \\
\hline スウェーデン:協力者」 & $44 \%$ & 23 & $89 \%$ & 明確な偏りなし \\
\hline 全体 & $46 \%$ & 23 & $21 \%$ & \\
\hline
\end{tabular}

\section{3. 日本への移住の関心の特徴と関係する要因}

本節では、まず $3-1$ で日本一の移住の関心の特徵につ いて整理し、次に3-2でそれと関係する要因について分 析する。

\section{3-1. 日本への移住の関心の特㣲}

まず、目的別の日本一の移住の関心の有無に関する設問 では、全体の約 40\%〜 50\%の回答者が就学、または就労目 的での一時的な移住に関心があると回答した。参考として 質問した長期休睱への関心はそれよりも高く、また子育て や老後生活への関心はそれよりも低い值となった。(表4)

\section{表 4 日本に一時的に移住したい回答者の目的別比率}

\begin{tabular}{|c|c|c|c|c|c|}
\hline 滞在先地域 & 就学 & 就労 & 長期休睱 & 子育て & 老後生活 \\
\hline 日本 & $46 \%$ & $40 \%$ & $75 \%$ & $18 \%$ & $23 \%$ \\
\hline
\end{tabular}

(複数回答)

次に、日本への希望移住期間に関する設問では、就学・ 就労目的の約 $90 \%$ 半年以上の居住を希望した。（図 1)

図 1 目的別の日本への希望滞在期間

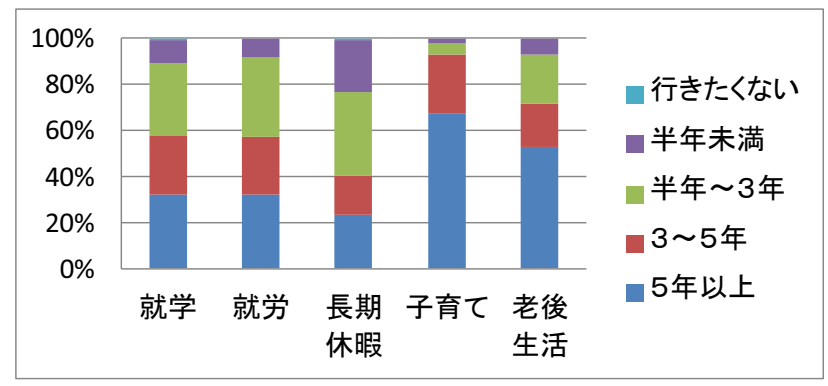

これらの移住に関する関心が、どのような情報の影響を 得ているかの参考として、日本に関する様々な情報源への 信頼度を 5 段階評価で質問した回答では、全体的に日本を 訪れた知人・家族の情報への信頼度が高い傾向にあった。 換言すれば、他者の主観的な意見に影響されて日本一の移 住関心がもたれている可能性が考えられる。（表5）

表 5 日本の情報源への信頼度の平均点（5段階評価）

\begin{tabular}{|l|c|}
\hline \multicolumn{1}{|c|}{ 日本に関する情報源 } & 信頼度 \\
\hline 政府や自治体の公式情報 & 3.9 \\
\hline 日本を訪れた知人・家族の情報 & 4.2 \\
\hline マスメディア(TV、雑誌等)の情報 & 3.7 \\
\hline Webコミュニティ(Blog、SNS等)の情報 & 3.7 \\
\hline 日本のコンテンツ(映画、音楽、文学等)での地域イメージ & 3.8 \\
\hline \multicolumn{2}{|l}{}
\end{tabular}

\section{3-2. 日本への移住の関心と関係する要因}

次に、日本の様々な生活環境を魅力的に感じるかどうか に関する 5 段階評価の回答結果を、就学・就職目的での移 住意向の有無によって比較した。その結果、言語環境、文 化の面白さ、生活の質、就業機会に対寸る魅力度に、移住 意向の有無によって有意な差が見られた。(表6)

集団面接調査では、文化的魅力への関心が各地域に共通 して見られた。例えば、アニメやドラマで描かれた日本の 生活像に憧れたことがきっかけで日本語を学習している学 生が多く見られた。日本と同じ漢字使用圈である台湾にお いてはこの傾向が特に強かった。また、生活の質や就業機 会への関心は台湾とタイで高く、米国では相対的に低かっ た。日本は台湾とタイからは生活水準や給与が高い地域と 見られているが、米国からは逆に低い地域と見られていた ことが影響していると考えられる。

表 6 日本の生活環境への魅力度の平均点（5段階評価）

\begin{tabular}{|c|c|c|c|c|c|}
\hline 滞在目的 & \multicolumn{2}{|c|}{ 就学 } & \multicolumn{2}{|c|}{ 就労 } & \multirow{2}{*}{$\begin{array}{c}\text { 全回答者 } \\
\text { 平均 }\end{array}$} \\
\hline 滞在意向の有無 & \begin{tabular}{|c|} 
滞在意向 \\
あり
\end{tabular} & \begin{tabular}{|c|} 
滞在意向 \\
なし
\end{tabular} & $\begin{array}{c}\text { 滞在意向 } \\
\text { あり }\end{array}$ & \begin{tabular}{|c|} 
滞在意向 \\
なし
\end{tabular} & \\
\hline 犯罪からの安全性 & 4.3 & 4.2 & 4.3 & 4.2 & 4.3 \\
\hline 災害からの安全性 & 3.4 & 3.3 & 3.2 & 3.3 & 3.3 \\
\hline 言語環境 & $3.4 * *$ & $2.9 * *$ & 3.2 & 3.1 & 3.1 \\
\hline 文化の面白さ & $4.5 *$ & $4.3 *$ & 4.5* & $4.3 *$ & 4.4 \\
\hline 生活の質 & 4.5 & 4.4 & 4.6* & 4.4* & 4.5 \\
\hline 生活コストの安さ & 3.1 & 3.2 & 3.1 & 3.1 & 3.1 \\
\hline 就業機会 & 3.7 & 3.5 & $3.9 * *$ & $3.4 * *$ & 3.6 \\
\hline 給料の多さ & 3.8 & 3.8 & 3.9 & 3.7 & 3.8 \\
\hline 住民の親切さ & 4.1 & 4.0 & 4.1 & 4.0 & 4.0 \\
\hline 外国人への政策の寛容さ & 3.7 & 3.7 & 3.8 & 3.6 & 3.7 \\
\hline
\end{tabular}

（*はt検定で $5 \%$ 有意、**は 1\%有意）

次に、日本で生活する際に、日本の文化や生活習慣に適 応することへの政策支援をどの程度期待するかに関する 5 段階評価を、就学・就職目的での移住意向の有無によって 比較した。その結果、言語、食文化、就労環境での適応意 向に、移住意向の有無によって有意な差が見られた。(表 7)

集団面接調査では、日本文化に関心を持つ者は、総じて 食文化に関する話題を提示しやすい傾向が見られた。また、 就労環境については、米国を中心に日本の長時間労働の印 象を䀣念寸る者がおり、評価がばらつく傾向が見られた。

\section{表 7 日本の生活習慣への適応意向の平均点（5段階評価）}

\begin{tabular}{|c|c|c|c|c|c|}
\hline 滞在目的 & \multicolumn{2}{|c|}{$\begin{array}{c}\text { 就学 } \\
\end{array}$} & \multicolumn{2}{|c|}{$\begin{array}{c}\text { 就労 } \\
\end{array}$} & \multirow{2}{*}{$\begin{array}{c}\text { 全回答者 } \\
\text { 平均 }\end{array}$} \\
\hline 滞在意向の有無 & $\begin{array}{c}\text { 滞在意向 } \\
\text { あり }\end{array}$ & $\begin{array}{c}\text { 滞在意向 } \\
\text { なし }\end{array}$ & $\begin{array}{c}\text { 滞在意向 } \\
\text { あり }\end{array}$ & $\begin{array}{c}\text { 滞在意向 } \\
\text { なし }\end{array}$ & \\
\hline 言語(language) & $4.4 *$ & $4.2 *$ & $4.5 * *$ & $4.1 * *$ & 4.3 \\
\hline 食(food) & 4.1 & 4.0 & $4.2 * *$ & $3.9 * *$ & 4.0 \\
\hline 住居 (housing) & 4.0 & 3.8 & 4.0 & 3.8 & 3.9 \\
\hline 衣服 (clothes) & 3.4 & 3.4 & 3.4 & 3.4 & 3.4 \\
\hline $\begin{array}{c}\text { 就労環境 } \\
\text { (company and work style) }\end{array}$ & 3.6 & 3.5 & $3.8 * *$ & $3.4 * *$ & 3.6 \\
\hline 友人(friends) & 3.7 & 3.7 & 3.8 & 3.7 & 3.7 \\
\hline $\begin{array}{c}\text { 配偶者 } \\
\text { (husband / wife / partner in } \\
\text { life) }\end{array}$ & 3.0 & 3.1 & 3.1 & 3.0 & 3.0 \\
\hline $\begin{array}{c}\text { 教育 } \\
\text { (education and self- } \\
\text { development) }\end{array}$ & 3.7 & 3.6 & 3.8 & 3.6 & 3.7 \\
\hline 信仰·宗教 (religion) & 2.6 & 2.6 & 2.6 & 2.6 & 2.6 \\
\hline $\begin{array}{c}\text { 趣味・スポーツ(hobby and } \\
\text { sports) }\end{array}$ & 3.3 & 3.4 & 3.3 & 3.4 & 3.3 \\
\hline
\end{tabular}

（*はt検定で $5 \%$ 有意、**は 1\%有意） 
次に、日本での大都市圈以外一の居住を魅力的に感じる かどうかに関する 5 段階評価の回答結果を、就学・就職目 的での移住意向の有無によって比較した。その結果、地方 都市と島しょ部一の居住に対する魅力度に、移住意向の有 無によって有意な差が見られた。(表 8)

集団面接調查では、東京・京都などの大都市以外の知名 度は低かった。相対的な都市部一の居住を希望する傾向が 強かったが、北海道・沖縄などの観光地の知名度が比較的 高く、それらの地域への居住への関心も少し見られた。

\section{表 8 日本の地方居住への魅力度の平均点（5段階評価）}

\begin{tabular}{|c|c|c|c|c|c|}
\hline 滞在目的 & \multicolumn{2}{|c|}{ 就学 } & \multicolumn{2}{|c|}{ 就労 } & \multirow[b]{2}{*}{$\begin{array}{c}\text { 全回答者 } \\
\text { 平均 }\end{array}$} \\
\hline 滞在意向の有無 & \begin{tabular}{|c|} 
滞在意向 \\
あり
\end{tabular} & \begin{tabular}{|c|} 
滞在意向 \\
なし \\
\end{tabular} & \begin{tabular}{|c} 
㴆在意向 \\
あり \\
\end{tabular} & \begin{tabular}{|c|} 
㴆在意向 \\
なし
\end{tabular} & \\
\hline 地方都市 (人口30万以上) & $4.1 *$ & $3.8 *$ & $4.2 * *$ & $3.8 * *$ & 4.0 \\
\hline 地方都市 (人口30万未満) & $4.1 *$ & $3.8 *$ & 4.0 & 3.9 & 3.9 \\
\hline $\begin{array}{c}\text { 農村地域(agricultural } \\
\text { village) }\end{array}$ & 3.3 & 3.1 & 3.2 & 3.2 & 3.2 \\
\hline 島しよ部(small island) & $3.3 * *$ & $2.9 * *$ & 3.2 & 3.0 & 3.1 \\
\hline 山間部 (mountain area) & 3.1 & 2.9 & 3.1 & 2.9 & 3.0 \\
\hline
\end{tabular}

（*はt検定で $5 \%$ 有意、**は $1 \%$ 有意）

最後に、日本の地域住民との交流活動を魅力的に感じる かどうかに関する5段階評価の回答結果を、就学・就職目 的での移住意向の有無によって比較した。その結果、例示 した多くの国際交流活動への参加に対する魅力度に、移住 意向の有無によって有意な差が見られた。(表9）

集団面接調查では、日本文化に関心を持つ者は、総じて 国際交流のイベントへの参加に対して関心を持つ傾向が見 られた。また、台湾などを中心に、震災復興などの支援活 動への参加に積極的な者も見られた。

表 9 住民との交流活動の魅力度の平均点（5段階評価）

\begin{tabular}{|c|c|c|c|c|c|}
\hline 滞在目的 & \multicolumn{2}{|c|}{ 就学 } & \multicolumn{2}{|c|}{ 就労 } & \multirow{2}{*}{$\begin{array}{l}\text { 全回答者 } \\
\text { 平均 }\end{array}$} \\
\hline 滞在意向の有無 & 滞在意向 & 滞在意向 & 滞在意向 & 滞在意向 & \\
\hline $\begin{array}{c}\text { 地域文化を学ぶ } \\
\text { ワークシシップ }\end{array}$ & $4.6 * *$ & $4.2 * *$ & $4.6 * *$ & $4.3 * *$ & 4.4 \\
\hline 地元のお祭りへの参加 & $4.7 * *$ & $4.4 * *$ & $4.7 *$ & $4.5 *$ & 4.5 \\
\hline $\begin{array}{l}\text { ホームステイ } \\
\text { /シェアハウス }\end{array}$ & 4.3 & 4.2 & 4.2 & 4.2 & 4.2 \\
\hline 自分の文化の紹介 & $4.2 * *$ & $3.9 * *$ & $4.2 *$ & $3.9 *$ & 4.0 \\
\hline $\begin{array}{c}\text { 社会的弱者(高齢者、災害 } \\
\text { 被災者、マイ少、テイ) } \\
\text { の支援活動 }\end{array}$ & 4.1 & 4.0 & $4.2 *$ & $3.9 *$ & 4.0 \\
\hline
\end{tabular}

（*はt検定で 5\%有意、**は1\%有意）

\section{4. 海外諸国への移住の関心の特徵と関係する要因}

次に、本節では、まず $4-1$ で海外諸国への移住の関心 の特徴について整理し、次に $4-2$ でそれと関係する要因 について分析する。

なお、海外諸国については、主にアジア太平洋地域にお いて国際的評価が高い大学が存在し、高度人材の誘致にお いて競争相手となる可能性が高いと思われる国を選択肢と して提示し、合わせてそれ以外の関心が強い任意の国に関 する評価の設問も用意した(ク。

\section{4-1. 海外諸国への移住の関心の特徵}

まず、目的別の海外諸国への移住の関心の有無に関する
設問では、米国や英国が日本以上に高い関心を持たれてい る結果となった。シンガポールは就労目的で、オーストラ リアとニュージーランドは長期休腵目的で高い関心を持た れていた。その他の国としては、ドイツ、フランス、イタ リア、スペイン、スウェーデンなどの欧州諸国を挙げる回 答が見られた。(表 10$)$

\section{表 10 海外諸国に移住したい回答者の目的別比率}

\begin{tabular}{|c|c|c|c|c|c|}
\hline 滞在目的 & 就学 & 就労 & 長期休暇 & 子育て & 老後生活 \\
\hline 日本(※再掲) & $46 \%$ & $40 \%$ & $75 \%$ & $18 \%$ & $23 \%$ \\
\hline 韓国 & $19 \%$ & $18 \%$ & $56 \%$ & $3 \%$ & $6 \%$ \\
\hline 中国(香港を除く) & $18 \%$ & $31 \%$ & $42 \%$ & $3 \%$ & $3 \%$ \\
\hline 香港 & $23 \%$ & $36 \%$ & $44 \%$ & $6 \%$ & $2 \%$ \\
\hline シンガポール & $26 \%$ & $46 \%$ & $37 \%$ & $11 \%$ & $7 \%$ \\
\hline オーストラリア & $35 \%$ & $35 \%$ & $67 \%$ & $23 \%$ & $27 \%$ \\
\hline ニュージーランド & $25 \%$ & $27 \%$ & $68 \%$ & $24 \%$ & $36 \%$ \\
\hline 米国 & $47 \%$ & $45 \%$ & $36 \%$ & $21 \%$ & $10 \%$ \\
\hline カナダ & $35 \%$ & $38 \%$ & $54 \%$ & $29 \%$ & $31 \%$ \\
\hline 英国 & $56 \%$ & $45 \%$ & $56 \%$ & $24 \%$ & $19 \%$ \\
\hline その他 & $22 \%$ & $17 \%$ & $26 \%$ & $12 \%$ & $16 \%$ \\
\hline
\end{tabular}

(複数回答)

海外諸国への希望移住期間に関する設問では、米国、英 国、カナダで日本以上に長期滞在への関心が強く見られた。 シンガポールのように、就労目的の関心が高い国でも希望 滞在期間が長くない場合も見られる。なお、その他の国と して挙げられた国は、表 10 と同様である。(図 2)

\section{図2 海外諸国への希望滞在期間の比較}

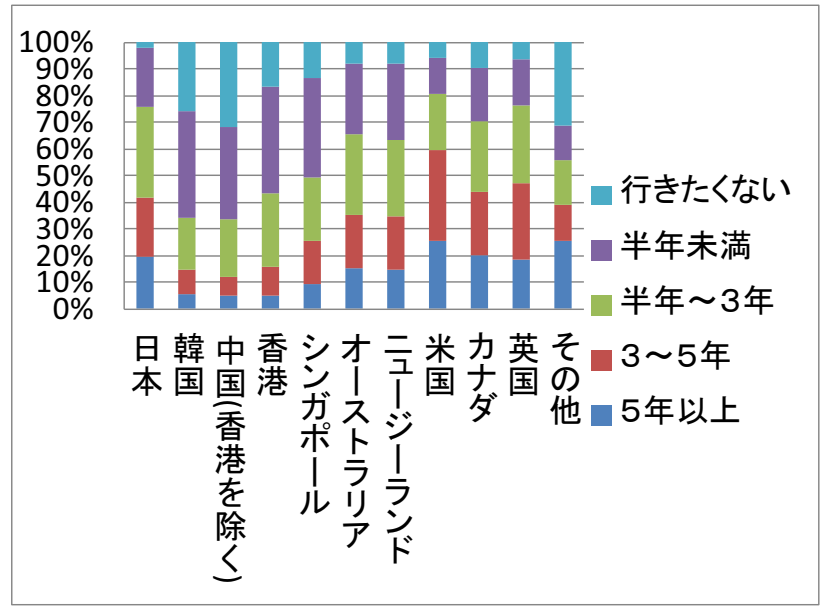

日本以外で最も滞在したい国に関する設問では、米国、 英国、ニュージーランド、ドイツなどの西洋文化圈の国が 上位となった。ニュージーランドは、集団面接調査で映画 の撮影場所として利用されたことから留学への関心を持っ たと回答した者が複数見られた。シンガポール、韓国など のアジア諸国を挙げる回答者も多く存在した。（表１１）

\section{表 11 日本以外で最も移住したい国の上位 15 力国}

\begin{tabular}{|l|r|l|r|r|r|}
\hline & 希望比率 & 国名 & 希望比率 & 国名 & 希望比率 \\
\hline 米国 & $15.8 \%$ & 韓国 & $5.3 \%$ & スイス & $3.0 \%$ \\
\hline 英国 & $14.2 \%$ & オーストラリア & $5.0 \%$ & ノルウェー & $1.7 \%$ \\
\hline ニュージーランド & $7.6 \%$ & フランス & $4.3 \%$ & スウェーデン & $1.7 \%$ \\
\hline ドイツ & $6.9 \%$ カナダ & $4.0 \%$ メキシコ & $1.7 \%$ \\
\hline ジン゙ポール & $5.6 \%$ & イタリア & $3.6 \%$ & 台湾 & $1.7 \%$ \\
\hline
\end{tabular}




\section{4-2. 海外諸国への移住の関心と関係する要因}

次に、日本以外で最も移住したい海外諸国の様々な生活 環境を魅力的に感じるかどうかに関する 5 段階評価の回答 結果を、就学・就職目的での移住意向の有無によって比較 した。その結果、日本に対寸る設問で見られたような言語 環境、文化の面白さ、生活の質、就業環境への評価に関す る明確な傾向は見られなかった(8)。(表 12 )

犯罪や災害からの安全性や生活コストの安さなどで、滞 在意向がある人の方が評価の低い結果となった箇所がある。 集団面接調査では、主に米国などを対象に、一時的な移住 を真剣に検討したことがある人の方が、その地域の課題に 関する実態を把握し、評価が低くなる場合が見られた。

\section{表 12 海外諸国の生活環境への魅力度の平均点（5段階評価）}

\begin{tabular}{|c|c|c|c|c|c|}
\hline 滞在目的 & \multicolumn{2}{|c|}{ 就学 } & \multicolumn{2}{|c|}{ 就労 } & \multirow[b]{2}{*}{$\begin{array}{c}\text { 全回答者 } \\
\text { 平均 }\end{array}$} \\
\hline 滞在意向の有無 & $\begin{array}{c}\text { 滞在意向 } \\
\text { あり }\end{array}$ & $\begin{array}{c}\text { 滞在意向 } \\
\text { なし }\end{array}$ & $\begin{array}{c}\text { 滞在意向 } \\
\text { あり }\end{array}$ & $\begin{array}{c}\text { 滞在意向 } \\
\text { なし }\end{array}$ & \\
\hline 犯罪からの安全性 & 3.8 & 4.0 & 3.8 & 4.1 & 3.9 \\
\hline 災害からの安全性 & 3.9 & 4.0 & 3.9 & 4.0 & 4.0 \\
\hline 言語環境 & 4.2 & 4.0 & 4.2 & 4.0 & 4.1 \\
\hline 文化の面白さ & 4.2 & 4.0 & 4.1 & 4.1 & 4.2 \\
\hline 生活の質 & 4.5 & 4.5 & 4.5 & 4.5 & 4.5 \\
\hline 生活コストの安さ & 3.1 & 3.3 & 3.1 & 3.4 & 3.2 \\
\hline 就業機会 & 4.0 & 4.0 & 4.1 & 3.9 & 4.0 \\
\hline 給料の多さ & 4.2 & 4.0 & 4.2 & 4.1 & 4.1 \\
\hline 住民の親切さ & 3.8 & 4.0 & 3.8 & 4.0 & 3.9 \\
\hline 外国人への政策の寛容さ & 3.8 & 3.7 & 3.8 & 3.8 & 3.8 \\
\hline
\end{tabular}

（*はt検定で $5 \%$ 有意、**は $1 \%$ 有意）

次に、日本以外で最も移住したい海外諸国で生活する際 に、その国の文化や生活習慣を学習し慣れることへの政策 的支援をどの程度期待するか関する 5 段階評価の回答結 果を、就学・就職目的での移住意向の有無によって比較し た。その結果、就労環境と教育環境での適応意向に、移住 意向の有無によって有意な差が見られた。（表 13 ）

就学目的での移住関心でも就労環境一の適応意向が強い のは、留学後に現地で就職する意向が強いことが影響して いることが推察される。また、就学目的の者が教育環境で の適応意向が強いのは自然と考えられる(9)。

\section{表 13 海外諸国の生活習慣への適応意向の平均点 ( 5 段階平価)}

\begin{tabular}{|c|c|c|c|c|c|}
\hline 滞在目的 & \multicolumn{2}{|c|}{ 就学 } & \multicolumn{2}{|c|}{ 就労 } & \multirow[b]{2}{*}{$\begin{array}{l}\text { 全回答者 } \\
\text { 平均 }\end{array}$} \\
\hline 滞在意向の有無 & $\begin{array}{c}\text { 滞在意向 } \\
\text { あり }\end{array}$ & \begin{tabular}{|c} 
滞在意向 \\
なし
\end{tabular} & \begin{tabular}{|c|} 
滞在意向 \\
あり
\end{tabular} & \begin{tabular}{|c|} 
滞在意向 \\
なし
\end{tabular} & \\
\hline 言語(language) & 4.3 & 4.2 & \begin{tabular}{|l|}
4.2 \\
\end{tabular} & 4.4 & 4.3 \\
\hline 食 (food) & 3.6 & 3.5 & 3.5 & 3.7 & 3.7 \\
\hline 住居 (housing) & 4.0 & 3.8 & 4.0 & 3.8 & 4.0 \\
\hline 衣服(clothes) & 3.6 & 3.4 & 3.6 & 3.5 & 3.6 \\
\hline $\begin{array}{c}\text { 就労環境 } \\
\text { (company and work style) }\end{array}$ & $4.0 * *$ & $3.7 * *$ & $4.1 * *$ & $3.7 * *$ & 3.9 \\
\hline 友人(friends) & 3.7 & 3.7 & 3.7 & 3.8 & 3.8 \\
\hline $\begin{array}{c}\text { 配偶者 } \\
\text { (husband / wife / partner in life) }\end{array}$ & 3.4 & 3.2 & 3.3 & 3.4 & 3.3 \\
\hline $\begin{array}{c}\text { 教育 } \\
\text { (education and self- } \\
\text { development) }\end{array}$ & $4.2 * *$ & $3.8 * *$ & 4.1 & 4.0 & 4.0 \\
\hline 信仰·宗教（religion） & 2.6 & 2.6 & 2.6 & 2.7 & 2.6 \\
\hline $\begin{array}{c}\text { 趣味・スポーツ(hobby and } \\
\text { sports) }\end{array}$ & 3.5 & 3.6 & 3.5 & 3.5 & 3.5 \\
\hline
\end{tabular}

（*はt検定で 5\%有意、**は 1\%有意）

次に、日本以外で最も移住したい海外諸国での大都市圈 以外一の居住を魅力的に感じるかに関する5段階評価の回 答結果を、就学・就職目的での移住意向の有無によって比 較した。その結果、地方中小都市一の居住に対する魅力度
に移住意向の有無によって有意な差が見られた。日本に関 する設問で見られたような島しょ部への魅力度に関する有 意差は見られなかったことから、移住関心に関係する日本 の島しょ部の魅力は、海外諸国にはあまりない日本独自の ものとして認識されている可能性が考えられる。(表 14 )

\section{表 14 海外諸国の地方居住への魅力度の平均点（5段階評価）}

\begin{tabular}{|c|c|c|c|c|c|}
\hline 滞在目的 & \multicolumn{2}{|c|}{ 就学 } & \multicolumn{2}{|c|}{ 就労 } & \\
\hline 滞在意向の有無 & 滞在意向 & 滞在意向 & 滞在意向 & 滞在意向 & $\begin{array}{c}\text { 王回合百 } \\
\text { 平均 }\end{array}$ \\
\hline 地方都市 (人口30万以上) & 4.1 & 4.0 & $4.2 *$ & $3.9 *$ & 4.1 \\
\hline 地方都市 (人口30万未満) & $4.1 * *$ & $3.8 * *$ & $4.2 * *$ & $3.7 * *$ & 4.0 \\
\hline 農村地域(agricultural village) & 3.2 & 3.0 & 3.1 & 3.2 & 3.2 \\
\hline 島しよ部(small island) & 3.0 & 3.1 & 3.0 & 3.1 & 3.1 \\
\hline 山間部 (mountain area) & 2.9 & 3.1 & 2.9 & 3.1 & 3.1 \\
\hline
\end{tabular}

（*はt検定で 5\%有意、**は1\%有意）

最後に、日本以外で最も移住したい海外諸国の地域住民 との交流活動を魅力的に感じるから゙うかに関する 5 段階評 価の回答結果を、就学・就職目的での移住意向の有無によ って比較した。その結果、例示したいくつかの活動への参 加に対して、移住意向の有無によって有意な差は見られな かった。(表15)

集団面接調查では、フランス、イタリアなどの欧州圈の 諸国への移住に関心を持つ者は、国際交流活動への参加に 対して関心が強い傾向が見られた。反面、米国・英国・シ ンガポールなどへの移住に関心を持つ者は、移住先での住 民との交流活動への関心が相対的に弱かった。表 11 に示 寸結果では後者の国々への移住を希望する回答者が多かっ たことから、交流活動への関心は全体的には弱かったと考 えられる。

\section{表 15 住民との交流活動の魅力度の平均点（5段階評価）}

\begin{tabular}{|c|c|c|c|c|c|}
\hline 滞在目的 & \multicolumn{2}{|c|}{ 就学 } & \multicolumn{2}{|c|}{ 就労 } & \multirow{2}{*}{$\begin{array}{c}\text { 全回答者 } \\
\text { 平均 }\end{array}$} \\
\hline 滞在意向の有無 & $\begin{array}{c}\text { 滞在意向 } \\
\text { あり }\end{array}$ & $\begin{array}{c}\text { 滞在意向 } \\
\text { なし }\end{array}$ & $\begin{array}{c}\text { 帯在意向 } \\
\text { あり }\end{array}$ & $\begin{array}{c}\text { 滞在意向 } \\
\text { なし }\end{array}$ & \\
\hline $\begin{array}{l}\text { 地域文化を学ぶ } \\
\text { ワークショップ }\end{array}$ & 4.4 & 4.2 & 4.3 & 4.3 & 4.4 \\
\hline 地元のお祭りへの参加 & 4.6 & 4.4 & 4.5 & 4.5 & 4.5 \\
\hline $\begin{array}{l}\text { ホームステイ } \\
\text { /シェアハウス }\end{array}$ & 4.2 & 4.2 & 4.2 & 4.3 & 4.2 \\
\hline $\begin{array}{c}\text { 自分の文化の紹介 } \\
\end{array}$ & 4.1 & 4.0 & 4.1 & 4.0 & 4.0 \\
\hline $\begin{array}{c}\text { 社会的弱者(高齢者、災害被災 } \\
\text { 者、マイノリティ) } \\
\text { の支援活動 }\end{array}$ & 4.1 & 4.1 & 4.1 & 4.0 & 4.1 \\
\hline
\end{tabular}

（*はt検定で 5\%有意、**は 1\%有意）

\section{5. 結論}

\section{5-1. 結果のまとめ}

3章で報告した日本への移住の関心と関係する要因とし ては、日本の言語・食環境への適応意向や、文化の面白さ・ 生活の質への関心、島しょ部への居住経験や国際交流活動 への参加への意欲など、文化的魅力と関係する要因がいく つか抽出された。一方、住居、衣服、友人など、文化的魅 力と関連しつつも、日本への移住の関心との間には有意な 関係性が見られない要因も多く存在した。他方、4 章で報 告した海外諸国への移住の関心と関係する要因としては、 文化的魅力と関係寸る要因の影響は相対的に弱く、就労環 境や教育環境など、就学や就労という移住の目的と直結す る要因が多く抽出された。 


\section{$5-2$. 考察}

これらの結果を踏まえると、海外若年世代の国際交流の 意向が、対象地域の文化的魅力への関心と関係がある、と いう仮説は、日本に対してはいくつかの要素に限定して当 てはまる結果になったが、海外諸国に対しては当てはまら ない結果になったと考えられる。この結果は、日本の文化 的魅力として捉えられる様々な要素の中に、若年海外高度 人材の関心を集めやすい要素と集めにくい要素とが混在し ていると解釈できる。それらを峻別するためには、より具 体的な文化交流の事例や質問項目を提示し、精度の高い形 で調査・分析を行うことが、今後の研究課題として求めら れる。例えば、本研究の面接調査で関心の高かった食文化 やアニメなどを参考に日本の生活像の事例を提示し、関心 の対象について考察する、などの方法が考えられる。

また、本研究の成果からは、海外からの一時的な移住を 促進する際に文化的魅力を訴求することの重要性が示唆さ れる。それと同時に、そのようなアプローチは全ての海外 諸国において有効なわけではなく、文化的魅力の蓄積のあ る日本だからこそ競争力のある戦略になる可能性も考えら れる。論文の冒頭で述べたような、パブリック・ディプロ マシ一やその手段としての文化交流を、海外高度人材の受 入促進施策として、大都市圈を対象とした地域政策に積極 的に位置付けていくことなども検討の余地があると考えら れる。特に、日本の都市計画分野においては、創造都市政 策や多文化都市づくりなどの形で、地域文化を活用したま ちづくりの事例が既に数多く蓄積されている(10)。例えば、 このような都市の文化的魅力を、自治体が主導して Webぺ ージや観光情報誌などの広報媒体や、あるいは国際交流事 業などと連携して海外に発信する計画や制度などが、国家 レベルでの政策を補完する役割を担うことも期待される。

他方で、本研究の調査結果では、調査対象者の偏りによ る影響なども想定され、この傾向を断定するためには、よ り精度の高い調査による検証が必要と考えられる。この点 も、今後の研究課題としたい。

\section{【謝辞】}

本研究に関わる調査の一部は、平成 26 年度国土政策関係研究支援事業の 助成を受けて実施しました。ご協力いただいた皆様に感謝申し上げます。

\section{【補注】}

(1) 参考文献5)などがその例として挙げられる。

(2) 参考文献6)などにその詳細な説明が存在する。

(3) 例えば、中国政府が海外の大学などの教育機関と提携し、中国語や中国 文化の教育及び宣伝、中国との友好関倸㘍をを目的に設立した孔子学院の 例などが挙げられる。

(4) 文化的要素以外には、「ビジネスにおける能力／業績主義の徹底「「ス リートにおける安全 /安心の確保」「家庭生活での文化的多様性の公的な承 認と支援」「租税負担の低さ」が挙げられ、これらの特徵を「ミドルクラス 多文化主義り と呼称している。

(5) アンケート調査および集団面接調査の実施スケジュールは次の通り。 アンケート調査 : 2014 年 12 月 (台湾)、2015 年 1２月（米国、スウェー デン、タイ)、集団面接調査 : 2014 年 9 月（米国）、2014 年 12 月（台湾）、 2014 年 2 月（タイ）※いずれも対象者が所属する大学内の教室で実施。 (6) なお、海外諸国に関する質問項目では、空白の回答が多く見られたため、 有効回答数が 235 件に減少している。このため、海外諸国に関する検定で
は検出力が相刘的に低くなる点に留意が必要である。このことは、アンケ ートの後半部分に設問を配置したために最後までに回答しなかった者がい たことや、提示した選护肢にない国を自由回答式で書いた回答者が、論理 的に矛盾した回答を行うのを防げなかったことなどが起因している。

（7）具体的には、日本以外に、韓国、中国（香港を除く）、香港、シンガポ 一ル、オーストラリア、ニュージーランド、米国、カナダ、英国を選护肢 として提示した。英国は、国際的評価が高い大学が特に多いことから、ア ジア太平洋地域ではないが選択肢に含めた。なお、米国で害施したアンケ 一トでは米国を移住先の選択肢から外した。大学の国際的評価については 参考文献 17)の 2014 年度版を参考にした

(8) ただし、日本に関する回答よりもサンプル数が減少しているため、統計 的な有意性が検出されにくい点に留意が必要である。この点は表 $13 \sim 1$ 5においても同様に当てはまる。

(9) ただし、表8の日本に関する回答結果において同様傾向が見られなかっ た点は解釈が難しい。例えば、日本の教育環境に対する期待があまり高く ないといら解釈や、反対に、日本の教育に期待しているからこそ、教育一 の政策的支援による介入の必要性が低い、という解釈が考えられる。 (10) まちづくりの事例としては、例えば参考文献18)19)などが挙げられる。

\section{【参考文献】}

1) 国土交通省(2015)，「国土形成計画（全国計画）」, http://www.mlit.go.jp/kokudoseisaku/kokudokeikaku fr3 000003.html 2) 内閣府地方創生推進事務局(2016), 「国家戦略特区 区域計画 (東京圏 H28.4.13 認定)，https://www.kantei.go.jp/jp/sing//tiki/kokusentoc/tokyoken.html 3) 法務省入国管理局ホームページ,「高度人材ポイント制とは?」

$\mathrm{http}: /$ www.immi-moj.go.jp/newimmiact_3/system/index.html（2016年4月 20 日 閲覽)

4) 明石純一(2014)，「国際人口移動に対寸る政策的管理の実効性と限界」,人 口問題研究（J.ofPopulationProblems） 70-3 (2014.9) pp.275 291 5) 経済産業省(2010),「「文化産業」立国に向けて一文化産業を2 1 世紀のリ ーディング産業に一」,

http:/www.meti.go.jp/committee/materials2/downloadfiles/g100405a04j.pdf 6) 外務省ホームページ，「文化外交」,

http://www.mofa.go.jp/mofai/comment/faq/culture/gaiko.html（2016年4月 20 日 閲覽)

7) 渡辺靖(2011)，「文化と外交: パブリック・ディプロマシーの時代」，中公 新書

8) 藤田結子(2008),「文化移民: 越境する日本の若者とメディア」, 新曜社 9) 塩原良和(2015),「グローバル・マルチカルチュラル・ミドルクラスと分 断されるシティズンシップ」, 五十嵐泰正, 明石純一編著「「グローバル人材」 をめぐる政策と現実」第 12 章pp222〜237,明石書店

10）高畑幸(2015)，「人口減少時代の日本における「移民受け入れ」とは 一政策の変遷と定住外国人の居住分布」,『国際関係・比較文化研究』(静岡 県立大学国際関係学部)

第 14 巻第 1 号 (2015 年 9 月)

11) 佐伯康考(2015), 「日本から新興国一の高度人材移動に関寸る経済学的研 究，産研論集（関西学院大学）４2 号 (2015.3)

12) 後藤純一-(2014), 「少子高齢化時代における外国人労衝者受入孔政策の経 済学的分析」, 国際経済

13) 大久保立樹・室町泰徳(2014)，「旅行ガイドブックとロコミの言語解析に よる訪日外国人の観光地イメージに関する研究 都市計画論文集 Vol. 49 No. 3 pp. $573-578$

14）李度潤・瀬田史彦(2014)「多文化共生」を重視した地域づくりという 観点加の自治体外国人住民政策に関寸る研究」，都市計画論文集 Vol.49 No. 3 pp. 1011-1016

15) 森田佳花(2015),「後発開発途上国功の留学生受入れに関する考察: 多 様な国からの留学生受入孔促進に向けて」, 留学交流 Vol.51 pp.47-58, 独立 行政法人日本学生支援機構

16) 今西珠美(2013), 「日本の旅行企業の海外進出行動の変遷」, 流通科学大 学論集一流通・経営編 第 26 巻第 1 号,pp43-67

17) QS World University Rankings $₫ 2014 / 15$,

http://www.topuniversities.com/university-rankings/world-university-rankings/2014 18）佐々木雅之・総合研究開発機構(2007)，「創造都市への展望一都市の文 化政策とまちづくり」，学芸出版社

19) 稲葉佳子(2008), 「オオクボ都市の力一多文化空間のダイナミズム」, 学 芸出版社 